WE ARE HERE 



\title{
WE ARE HERE
}

\section{Politics of Aboriginal Land Tenure}

\author{
Edited by \\ EDWIN N. WILMSEN
}

University of CALIfornia Press 
University of California Press

Berkeley and Los Angeles, California

University of California Press, Ltd.

London, England

Copyright $(1) 1989$ by The Regents of the University of California

\section{LIBRARY OF CONGRESS}

\section{Library of Congress Cataloging-in-Publication Data}

We are here: politics of aboriginal land tenure/edited by Edwin N. Wilmsen.

p. $\mathrm{cm}$.

Bibliography: $\mathrm{p}$.

Includes index.

ISBN 0-520-06300-7

1. Native races. 2. Land tenure. 3. Land tenure (Primitive law)

I. Wilmsen, Edwin N.

GN449.3.W4 1989

333.3'089011-dc19 88-17500 CIP

Printed in the United States of America

$\begin{array}{lllllllll}1 & 2 & 3 & 4 & 5 & 6 & 7 & 8 & 9\end{array}$ 